\title{
Determinants of effective outsourced private security services by commercial banks in Nairobi, Kenya
}

\author{
Anthony Andrew Wachira Githae \\ Department of Criminology \& Security Management \\ Dedan Kimathi University of Technology \\ Prof. Matthew Mwangi Theuri, PhD \\ Department of Criminology \& Security Management \\ Dedan Kimathi University of Technology \\ Dr. Ruth Joyce Nyawira Kaguta, PhD \\ Department of Criminology \& Security Management \\ Dedan Kimathi University of Technology
}

\begin{abstract}
The study intended to examine the determinants of effective outsourced private security services by commercial banks in Nairobi, Kenya. The study aimed at exploring effectiveness of factors to consider, technology, relationship between vendor and other security stakeholders and challenges involved while procuring private security services to commercial banks. The study employed descriptive research design. The population of the study was 40 commercial banks in Kenya where a total population of 240 security officials employed in the security departments of the commercial banks was used. A sample of 150 respondents was picked. A questionnaire was used to collect primary data. Study results reveal that factors that the commercial bank considered before outsourcing private security services had a positive and significant effect on effectiveness of outsourced private security services by commercial banks. However, technology applied by the private security companies in providing security to commercial banks did not have a significant effect on effectiveness of outsourced private security services by commercial banks. Study findings further revealed that the relationship between the private security companies and other security stakeholders had a positive and significant effect on effectiveness of outsourced private security services by commercial banks. Additionally, study results show that challenges that emanate from outsourced private security services had a negative and significant effect on effectiveness of outsourced security services to commercial banks. The study recommends that the government should fast-track the private security regulations to enhance the quality and standard of private security services.
\end{abstract}

Key words: Outsourced, security, technology, relationships, effectiveness.

\section{INTRODUCTION}

This study sought to explore the determinants of effectiveness related to outsourcing private security services by commercial banks in Nairobi, Kenya. This was based on the fact that all commercial banks in Kenya have outsourced security services which provide security solutions to their individual headquarters as well as their branch network round the country. Despite this very noble initiative, these banks still experienced security challenges. It is this lacuna that the study sought to explore and at the end of it all suggest some relevant solutions that the banks could use and apply to mitigate or surmount the underlying challenges. Commercial banks in Kenya were not the only ones that use outsourced private security as this practice has been used in many other countries all over the world and for various reasons. 
For instance, in Australia, outsourcing security services by private businesses is common. Australian businesses outsource security services to save on cost, access superior technology and expertise, and all-day support [1]. Running an in-house security team means hiring and paying salaries and benefits, creating office space and overall operational costs. By outsourcing security, private business only pays for services. Further, when outsourcing security, a business hires a company whose sole business is securing its businesses. This means, managed security service providers have the best hardware and software and skilled personnel. Moreover, security is a sensitive area and so all managed security service providers offer support all-day, all year as long as the contract is valid.

In United Kingdom, McIvor observed that many commercial banks prefer outsourcing non-core services like security rather than having a department that caters for such [2]. This is seen both as a strategic and operational tactic to save costs and focus on their core business of providing financial services. However, McIvor observed that outsourcing security services by commercial banks offered a few challenges which included bringing new security threats, lack of control and having contract termination issues. When commercial banks sign a contract with private security companies, they lose control over the choice of security software and hardware the company will use which can easily be manipulated and exploited by the provider and this makes it possible for new security threats crop up. The more access to the bank's sensitive areas and a third-party security service supplier has, the more risks of crime and data leakage the bank runs. Similarly, there might be contract termination issues that may entail additional stress and costs.

Fan argued that the practice of outsourcing security services by financial institutions has been in Nigeria for long [3]. There are various reasons that he puts forward which have contributed to the popularity of security outsourcing in that country. Firstly, it is risk transfer: - when commercial banks outsource security guard services, they transfer some of the liability risk to the security guard company. Secondly, a licensed security guard company should have the expertise and experience to avoid potential risks. They are also insured to cover all sorts of problematic scenarios. Most banks find themselves not capable to handle security risks at reasonable costs. Furthermore, a commercial bank gets great service at a reasonable cost. The private security company handles the start-up costs associated with hiring security guards as well as purchasing equipment and uniforms which form large savings for commercial banks.

In South Africa, there is not adequate public security to cater for private businesses effectively and therefore, these businesses like commercial banks turn to private security companies for security services [4]. In that respect therefore, these authors observed that outsourcing security by commercial banks frees up plenty of time and thus, allowing the banks to focus on other pressing business matters. For instance, commercial banks need not advertise open security positions or interview applicants. Moreover, hiring the right security professionals can often be a laborious process. The commercial banks have to examine each applicant's level of training, criminal background, work history, references and more. This makes security outsourcing attractive in South Africa. Additionally, the security company handles the guards' uniforms, salaries, work schedules, vacation time and such operational issues.

The practice of outsourcing of facilities management services in Uganda is becoming common as more and more private businesses outsource security for their facilities [5]. Although some commercial banks have internal security arrangements, in Uganda, majority of the security services are outsourced from private providers. The most popular services to be outsourced by commercial banks were security and catering. The most common driver for outsourcing was the necessity to gain quality services from another organisation's expertise. For the 
commercial banks that procure security services, the most common motivation to do so is the desire to focus on key business and reduce the cost of operations.

In Tanzania, security costs are among the most expensive in modern businesses [6]. Most businesses in the country are looking to cut costs and increase returns and outsourcing security goes a long way in achieving this. Although outsourcing tasks such as call handling or cleaning is easy, outsourcing security can be a risk or costly if not done properly. However, when done according to the laid down procedures, they are cheaper and efficient compared to an in-house security team.

Machua [7] in assessing outsourcing strategies among commercial banks in Kenya observed that commercial banks outsource a number of functions such as security services, transportation services, Automated Teller Machine management services, training of employees and recruitment services. Some functions which are core to the banks are not outsourced and they include facility appraisal and account opening. Some functions are fully outsourced such as security services, catering services, Automated Teller Machine management services as well as advertising and marketing. The most prevalent challenges of outsourcing among commercial banks in Kenya include; resistance to change, inability to develop clear outsourcing objectives, lack of proper communication to stakeholders, lack of top management support and lack of supporting structures. Wanjohi [8] observed that the key benefit of outsourcing security services in Kenya was that the firms received the best quality of the security services, which enhanced better performance in the firms. Further, Wanjohi revealed that although outsourcing security services was of benefit in the firms, there were some risks involved. There are various risks involved in outsourcing security services in Kenya. These include underestimated hidden costs, lack of internal organizational privacy, loss of full control of internal security systems and lack of adequate information on the potentials of the outsourced security firms [9]. All said and done, the main benefit of outsourcing security services by Kenyan businesses included getting good quality of the security services which in turn enhanced better performance in the firm.

Despite outsourcing security services from private security companies, commercial banks in Kenya continue to report various incidences of fraud and security breaches which have resulted to massive losses to the banks. In 2016, the Banking Fraud Investigation Department (BFID) reported that the cases of fraud and security breaches reported by commercial banks were 513. This was a year-on-year drop from the drop 605 cases reported in 2015 and 661 that were reported in 2014. Specific cases reported in 2016 include 32 cases of card fraud, 177 cases of cheque fraud, 64 cases of forgery and 83 cases of identity theft. In these cases, approximately KES 330 million was lost [10]. Though the numbers of cases reported have decreased over the years, the number of cases is still significant, and the amount of money lost substantial. This indicates that there is some inefficiency on how the commercial banks are secured since these cases fall in the domain of outsourced security. This informed this study that sought to explore the determinants of effectiveness of outsourced private security services to commercial banks in Nairobi, Kenya.

\section{Statement of the Problem}

It is the responsibility of every government to procure and safeguard commercial banks and other entities within its jurisdiction. There are many commercial banks in Kenya and to boost security services, they have engaged private security companies for their services. The effectiveness of these companies need to be studied because despite their presence, a number of banks have had huge losses from fraudsters and armed robbers among others. 
Hence the study explored the determinants of effective outsourced private security services by commercial banks in Kenya since banks are important commercial entities contributing to the economic growth of Kenya. Despite various measures that have been taken by commercial banks to enhance their individual internal security, banks continue to experience major security shortcomings which expose them in terms of their protection.

In spite of all these realizations, and the growing demand for private security services, few studies have been carried out on determinants of effective outsourced private security services by commercial banks in Kenya. This study therefore addressed these gaps associated to the challenges.

\section{Theoretical Framework}

\section{LITERATURE REVIEW}

This study will be guided by the routine activity theory developed by Felson [11] and Cohen and Marcus [12]. The routine activity theory suggests that when motivated offenders and suitable targets meet in the absence of capable guardians, crime is likely to happen. In other words, the absence of any of these three conditions or elements might be enough to prevent a crime from occurring. The theory's proponents also emphasize how overarching social conditions contextualize and define the everyday activities of people. Situated within the broader framework of environmental criminology, routine activity theory suggests that reducing criminal opportunities serves a key role in reducing the prevalence of crime [13]. Similarly, routine activity theory argues that the likelihood of crime increases or decreases based on the existence of these three elements.

Moreover, Cohen and Felson suggested how their theory applies to studying crime trends at varying macro and micro levels of analysis, ranging from national crime rates to a particular individual or location. The theory examines the environmental context in which crimes occur [14]. Routine activities are a theory of place, where different social actors intersect in space and time. The people we interact with, the places we travel to, and the activities we engage in influence the likelihood and distribution of criminal behavior. Specifically, the theory focuses on the intersections of motivated offenders, suitable targets, and the absence of capable guardians [12].

This theory was used in the study to explain factors to consider, the effect of technology, the effect of relationship between vendor and other security stakeholders and challenges involved can influence effectiveness of outsourced private security. Moreover, the theory also explained the link between regulation of private security and the effectiveness of outsourced private security. The four independent variables in the study (factors to consider, vendor relationship with other stakeholders, use of technology and challenges involved) are key aspects which are aimed at making private security companies to be capable guardians to reduce crime targeted at commercial banks.

\section{Empirical Review}

\section{Factors to consider while outsourcing private security services}

Ayienda and Muturi [15] investigated the factors influencing the adoption of service outsourcing among commercial banks in western Kenya. The study noted that intense competitive pressures had forced commercial banks to re-consider their methods in managing their outsourcing strategies, with a focus on core competencies, where much of the traditional in-house operations and activities had been subcontracted to outside suppliers. This study targeted 65 respondents from commercial banks in western Kenya and adopted a descriptive survey design to collect data through questionnaire survey. The study results revealed that 
commercial banks considered quality of service, vendor experience and reputation and costbenefit in making the outsourcing decision.

The study by Sesi [16] on the implementation of outsourcing strategies by commercial banks in Kenya established that outsourcing by commercial banks had resulted in various benefits. These included improved focus on core competence, better operational control and efficiencies, gaining competitive advantage, gaining access to new technology and skills, risk management, quality control, increased focus on core competence and increased productivity. The study determined that factors that banks greatly considered in successful implementation of the outsourcing strategy were experience and reputation of the vendor, cost efficiency of the outsourcing, innovative capacity, and technology used, and support services availed by the vendor. Other factors included the effectiveness of communication and collaboration between vendor and clients and integrity and competence of vendor employees.

\section{Effect of technology on outsourced private security services}

In a study by Gatoto, Wachira and Mwenda [17] on service quality strategies by private security firms in Kenya, the authors established that technology was a key factor that determined the quality of security service provided by these security firms. The authors observed that, in the ever-changing world of private security, protection officers' roles and responsibilities are quickly adapting to a heightened security environment. Protection officer suppliers are turning to advanced training - in everything from the latest high-tech CCTV system to anti-terrorism - in order for their officers to be ready for whatever corporate security assignments come their way. Security companies that are quick to adopt innovative ways and current technology are perceived to provide quality security services to their clients.

Te, Kadar, Brüngger and Cvijikj [18] sought to explore the contribution of technology in private security patrol and crime prevention information system on crime level and safety perception. The study was informed by the fact that crime reduction had become one of the major issues of the modern society. In order to achieve public reassurance, police forces and private security companies all over the world are undertaking actions to involve citizens in crime prevention through community policing. In parallel, technological platforms are deployed in order to share crime-related information with the public and to support the development of problem-solving strategies. However, the authors noted that the impact of these initiatives in terms of quality of security services, crime reduction and perception had not been sufficiently investigated yet. The study results showed that though adoption of technology had been significant in private as well as public security providers, the effect it has on quality of services and perception of security was minimal.

\section{Effect of relationship between the vendor and other security stakeholders}

Bures and Carrapico [19] conducted a study that explored the importance of relationships and collaborations amongst security companies and other stakeholders to improve private security. The study further explored the diversity within private-public collaborations and its consequences for security governance and service quality. The study established that private security companies offered key services that bridged the gaps that are left by the inadequacies of the public security services. Moreover, the study determined that though private security companies provided security services for profit, the government need to effectively regulate the sector by continuously introducing technical and legal regulations to make the sector more effective. Moreover, other stakeholders including the public, current clients and potential clients need to participate and collaborate with private security companies to make them more effective on providing quality security services. 
In a study on how effectiveness and quality of outsourced security services could be improved, van Steden and Sarre [20] assessed the relationship between the various security holders on the private security sector. The study established that in the various countries studied such as Nigeria, Kenya and South Africa, private security companies offered very poor-quality security services. The study further noted that though private security has been significantly on the rise worldwide, the quality had not improved. The study revealed that state institutions, such as the police service, are fundamental in enabling and guiding the practice of private policing and security industries. The government cannot avoid their obligation to regulate contract guards to ensure a fair and effective protection of their citizenry. There needs to be effective collaborations between the various players in the security industry to ensure that private security services offered attain the required standards.

\section{Challenges involved in outsourcing private security services}

A study by Temitope [21] in Nigeria investigated the outsourcing and performance of Commercial Banks in Lagos, Lagos State. The study assessed the challenges facing outsourcing in the commercial banking industry in Nigeria. The study utilized primary data that was collected using in-depth interviews. The in-depth interview was conducted on five employees of each of the 10 commercial banks which had their headquarters in Lagos. The study findings indicated that majority of staff in the commercial banking industry were being outsourced and the staffs were spread across five activities including security. The study also established that the challenges of outsourcing included financial risk, poor planning for the outsourced services, increase in the cost of outsourcing provisions and administration, failure to adhere to quality standards, dilution of control, poor structure to manage the outsourcing function effectively and increase in banks' liabilities to third parties. Other challenges established from the study included lack of compliance with contract terms, provision of unclear specifications and resistance from internal staff.

Sesi [16] conducted a study that investigated the challenges of implementing outsourcing strategies by commercial banks in Kenya. The study targeted all the 44 commercial banks that were operational at the time and used questionnaires to collect data. The study used various variables to determine how effective commercial banks were in implementing the outsourcing strategy and establish the challenges faced by commercial banks in implementing the outsourcing strategy. The study established that the greatest challenges experienced by the commercial banks in the outsourcing implementation process were inadequate resources availed for the implementation processes and ineffective management of the process.

Machua [7] conducted a study on the outsourcing strategies among commercial banks in Kenya. The study was a cross sectional questionnaire survey that targeted 43 commercial banks operating in Kenya. Primary data was used in the study and this data was collected through questionnaires. The study established that commercial banks in Kenya outsourced a number of functions including Automated Teller Machine management services, recruitment services, training of employees, transportation services and security services. Some functions are core to the banks and are not outsourced and include facility appraisal and account opening. The study also determined that banks fully outsourced security services. The most predominant challenges that the commercial banks encountered in their outsourcing included lack of effective supporting structures, inability to develop clear outsourcing objectives, resistance to change, lack of proper communication to stakeholders and lack of top management support. 


\section{METHODOLOGY}

The study employed descriptive research design for it portrayed an accurate profile of situations [22]. The design helped the researcher to obtain information concerning the current status on the determinants of effective private security services to commercial banks in Nairobi Kenya. A descriptive research determines and reports the way things are and attempts to describe such things as behaviour, attitudes, values, characteristics and perceptions. This is also stated by Gay [23] that descriptive study determines and reports the way things are and commonly involves assessing attitudes and opinions towards individuals, organizations and procedures. Kothari [24] suggests that for descriptive studies, ten per cent of the accessible population is enough for a study.

For the purpose of this study, the target population which should be accessible was the bank security managers. All the 40 registered commercial banks in Nairobi were considered in this study [25]. Each commercial bank has at least six officials dealing with security issues and which include private security managers and their personnel who work closely with the bank. This will make the population of the study to be 240 respondents. The population of this study was categorised into three different bank tiers which have been established after considering the branches that each bank had, transaction volume and customer base all over the country.

Out of a total population of 240 respondents, 150 respondents were selected through simple random sampling procedure. This sampling technique was selected for this study because it selected a sample without bias from the target or accessible population and this is to ensure each of the target population members has an equal and independent right of being included in the sample. Based on this, the researcher was able to adopt a mathematical formula for the purpose of determining the sample size. Kothari [24] has suggested the following mathematical formula for determining sample size.

$$
\mathrm{n}=\frac{N}{1+N(e) 2}
$$

Where, $\mathrm{n}$ is the sample size and then $\mathrm{N}$ is the total number of security officials targeted by the researcher or the population size, and e is the error or confidence level. The conventional confidence level of $95 \%$ was used to ensure a more accurate result from the sample. Based on this, the error term would equal to 0.05 or significance level. Using the total population of 400 and error margin of 0.1 , the sample size is calculated as follows.

$$
\begin{aligned}
\mathrm{n} & =240 /[1+(240 \times 0.0025)] \\
& =230 / 1.6 \\
\mathrm{n} & =150
\end{aligned}
$$

Hence, out of the total population of 240 security officials, a sample size of 150 was selected. A simple random sampling technique was then adopted to select the 150 respondents meaning that each of the 40 commercial banks would have at least 3 respondents each. The questionnaires were distributed to all the 40-bank headquarters where employees in the security department or unit were the target respondents.

A questionnaire was used to collect data. The questionnaire had both open and close-ended questions. The close-ended questions provided more structured responses to facilitate tangible recommendations. The closed ended questions wereused to test the rating of various attributes and this helped in reducing the number of related responses in order to obtain more valid responses. The open-ended questions provided additional information that might not have been captured in the close-ended questions. 
The questionnaire was carefully designed and tested with a few members of the population for further improvements. This was done in order to enhance its validity and accuracy of data to be collected for the study. Regarding collection of data, the researcher printed copies of the questionnaire and distributed them to various security managers and for their officers who include outsourced private security supervisors working with the bank and their bosses at their head offices during the quarterly meeting of the Kenya Bankers Association security committee that is attended by all commercial banks security managers to deliberate on various security challenges affecting banks. Those that were not picked were distributed to respective commercial banks by the researcher. Later, the filled questionnaires were taken to a central point in Nairobi city center where they were picked by the researcher for analysis.

Before processing the responses, the completed questionnaires were edited for completeness and consistency. The data will then be coded to enable the responses to be grouped into various categories. Descriptive statistics such as means, standard deviation and frequency distribution were used to analyse the data.

Quantitative techniques were used to analyze the closed-ended questions where a computer program (SPSS software) and MS Excel were used. Tables and figures were used appropriately to present the data collected for ease of understanding and analysis. This enabled the researcher to summarize responses for further analysis and to facilitate comparison. Qualitative data was analysed through content analysis and presented in prose form.

The ordinary least squares regression model was used to measure the effect of the independent variables on the effectiveness of private security outsourced by commercial banks. The regression model helped to explain the magnitude and direction of effect of the independent variables on the dependent variable. The model that was applied was as follows;

$$
\text { EOPS }=\beta_{0}+\beta_{1} F+\beta_{2} T+\beta_{3} R+\beta_{4} C+\mathscr{E}
$$

Where:

EOPS = Effectiveness of outsourced private security

$\mathrm{F}=$ Factors considered by commercial banks while outsourcing private security services

$\mathrm{T}=$ Technology

$\mathrm{R}=$ Relationship between the vendor and other security stakeholders

$\mathrm{C}=$ Challenges involved in outsourcing effective private security services

$\beta_{0}=$ Constant

$\beta i(i=1,2,3,4,5)=$ The coefficients for the various independent variables

$\mathscr{E}$ is the error term which is assumed to be normally distributed with mean zero and constant variance. The analyzed data was presented in form of tables, charts and graphs.

\section{FINDINGS AND DISCUSSION}

Out of the 150 questionnaires sent, only 104 questionnaires were received back fully completed making a response rate of 69 per cent. On the respondents' gender, the study found that majority of the respondents (68\%) was male whereas only $32 \%$ of the respondents indicated to be female. As regards the age of the respondents, the study found out that majority of the respondents as shown by $72 \%$ were aged between $41-50$ years, $13 \%$ were aged 51 years and above, $9 \%$ were aged between $26-35$ years and finally only $7 \%$ of the respondents were aged 36-40 years. On the component of the educational level, the study results reveal that $82 \%$ of the respondents had acquired university level of education while $18 \%$ indicated that they had acquired college level of education. The study also wanted to establish the duration in years that the respondents had worked in their various commercial banks. It was found out 
that $42 \%$ of the respondents had worked for over 10 years, $31 \%$ had worked in the commercial banks for less than 5 years, whereas $27 \%$ had worked for between 5 to 10 years.

\section{Effectiveness of Outsource Security Services to Commercial Banks in Kenya}

The study had sought to establish the effectiveness of the outsourced private security services by commercial banks. To assess the effectiveness, various service delivery indicators were provided and respondents to rate the level of security service provided by their outsourced security vendor using 5-point rating scale. Analysis was conducted through frequencies, percentages, means and standard deviations. Results are presented in Table 1.

Table 1: Effectiveness of Outsourced Security Services

\begin{tabular}{|c|c|c|c|c|c|}
\hline & & Frequency & Percent & Mean & Standard deviation \\
\hline \multirow{4}{*}{ Reliability } & Fair & 10 & 10 & \multirow{4}{*}{3.64} & \multirow{4}{*}{0.869} \\
\hline & Good & 34 & 33 & & \\
\hline & Very good & 43 & 41 & & \\
\hline & Excellent & 17 & 16 & & \\
\hline \multirow{4}{*}{ Responsiveness } & Fair & 13 & 13 & \multirow{4}{*}{3.56} & \multirow{4}{*}{0.748} \\
\hline & Good & 23 & 21 & & \\
\hline & Very good & 65 & 62 & & \\
\hline & Excellent & 3 & 3 & & \\
\hline \multirow{4}{*}{ Empathy } & Fair & 22 & 21 & \multirow{4}{*}{3.28} & \multirow{4}{*}{0.830} \\
\hline & Good & 34 & 33 & & \\
\hline & Very good & 45 & 43 & & \\
\hline & Excellent & 3 & 3 & & \\
\hline \multirow{3}{*}{ Quality assurance } & Fair & 10 & 10 & \multirow{3}{*}{3.52} & \multirow{3}{*}{0.668} \\
\hline & Good & 30 & 29 & & \\
\hline & Very good & 64 & 61 & & \\
\hline \multirow{4}{*}{$\begin{array}{l}\text { The physical presence of the } \\
\text { private security service } \\
\text { company in the locations } \\
\text { where your branch is situated }\end{array}$} & Fair & 7 & 7 & \multirow{4}{*}{3.89} & \multirow{4}{*}{0.888} \\
\hline & Good & 23 & 24 & & \\
\hline & Very good & 41 & 42 & & \\
\hline & Excellent & 26 & 27 & & \\
\hline
\end{tabular}

The results presented in Table 1 reveal that 43\% rated outsourced private security service as very good on reliability. The mean was 3.64 which also indicated that the respondents viewed outsourced private security as very good. Additionally, outsourced private security services were rated as very good on responsiveness by $63 \%$ of the respondents with the mean score also indicating the services were very good (mean =3.56). Additionally, $45 \%$ of the respondents rated outsourced private security services on empathy as very good. However, mean score (3.28) indicated that respondents rated the outsourced private service as good on empathy. Regarding quality assurance of the outsourced private security services, respondents rated the services as very good (mean $=3.52$ ). Respondents rated the security companies as very good (mean $=3.89$ ) on the physical presence of the private security service company in the locations where the bank branches situated. These findings indicate that outsourced security service received a good rating from the respondents. This can be attributed to the fact that commercial banks outsource vendors who have good reputation in provision of security services locally or internationally. Moreover, commercial banks sign Service Level Agreements (SLAs) with these security service vendors and hence this is an indication that these security companies are bound by these SLAs. 


\section{Factors Considered When Outsourcing Security}

The first objective of the study was to establish the factors considered by commercial banks while outsourcing private security services by commercial banks in Nairobi Kenya. To attain this objective, respondents were required to indicate their level of agreement to the statements listed in relating to the factors the commercial banks consider when outsourcing private security services. The rating was on a five-point scale. Means and standard deviations were used to analyze the responses and results are as presented in Table 2.

Table 2: Factors Considered When Outsourcing Security

\begin{tabular}{lcc}
\hline Statement & Mean & Standard deviation \\
\hline $\begin{array}{l}\text { The reputation of the vendor in the banking sector } \\
\begin{array}{l}\text { The reputation of the vendor in other sectors apart from the } \\
\text { banking sector }\end{array}\end{array}$ & 4.40 & .842 \\
\hline $\begin{array}{l}\text { The capacity of the private security company to effectively } \\
\text { provide bank with the services }\end{array}$ & 4.81 & .396 \\
\hline $\begin{array}{l}\text { Any previous cases of security breach involving the private } \\
\text { security company }\end{array}$ & 3.87 & 1.262 \\
\hline $\begin{array}{l}\text { The costs of the outsourced security services } \\
\text { she benefits that will be derived by the bank by outsourcing }\end{array}$ & 4.32 & .672 \\
\hline $\begin{array}{l}\text { The capacity of the private security company to communicate, } \\
\text { coordinate and interact with employees of the bank }\end{array}$ & 4.02 & .830 \\
\hline $\begin{array}{l}\text { The risks that can arise from the bank outsourcing security } \\
\text { services }\end{array}$ & 4.11 & .923 \\
\hline $\begin{array}{l}\text { The infrastructure (including technology and vehicles) the } \\
\text { security company has }\end{array}$ & 4.37 & .803 \\
\hline $\begin{array}{l}\text { Their ability to identify and speed in resolving emerging or } \\
\text { outstanding security related issues affecting their client }\end{array}$ & 4.44 & .500 \\
\hline $\begin{array}{l}\text { Guard remuneration } \\
\text { Availability of serviceable physical resources to enable the } \\
\text { company to serve the client effectively }\end{array}$ & 4.11 & .765 \\
\hline
\end{tabular}

Results in Table 2 reveal that respondents strongly agreed that commercial banks considered the capacity of the private security company to effectively provide bank with the services (mean $=4.81$ ). Findings also revealed that the respondents agreed to all other statements provided. These results show that commercial banks considered the availability of serviceable physical resources to enable the security company to serve the client effectively (mean $=4.48$ ), the ability of the security company to identify and speed in resolving emerging or outstanding security related issues affecting their client (mean $=4.44$ ), the reputation of the security services vendor in the banking sector (mean $=4.40$ ), the infrastructure (including technology and vehicles) the security company has (mean $=4.37$ ), and the costs of the outsourced security services (mean $=4.32$ ). Other factors considered by commercial banks included guard remuneration (mean $=4.11$ ), the risks that can arise from the bank outsourcing security services (mean $=4.11$ ), the benefits that will be derived by the bank by outsourcing security services (mean $=4.10$ ), the reputation of the vendor in other sectors apart from the banking sector (mean $=4.03$ ) and any previous cases of security breach involving the private security company (mean $=3.87)$.

These results reveal that commercial banks mainly considered factors such as capacity, physical resources, reputation of the vendor in the banking sector, cost, risk and benefits of the outsourced security service. These findings concur with the results by Sesi (2014) that factors 
that banks greatly considered in successful implementation of the outsourcing strategy were experience and reputation of the vendor, cost efficiency of the outsourcing, innovative capacity, and technology used, and support services availed by the vendor. Other factors included the effectiveness of communication and collaboration between vendor and clients and integrity and competence of vendor employees.

\section{Technology and outsourced private security services}

The second objective of the study was to articulate the effect of technology on outsourced effective private security services by commercial banks in Nairobi, Kenya. Several questions were raised to the respondents regarding technology applied for security purposes. First, respondents were requested to indicate their level of agreement to the statements listed in relation to technology used by the private company that provides the bank with security services. Means and standard deviations were applied in analysis and results are as indicated in Table 3.

Table 3: Technology applied by the private security companies

\begin{tabular}{lcc}
\hline Statement & Mean & Standard deviation \\
\hline $\begin{array}{l}\text { The security company uses up to date technology in } \\
\text { providing security for the bank }\end{array}$ & 3.61 & .600 \\
$\begin{array}{l}\text { The security company provides the guards in this bank } \\
\text { with the latest security equipment }\end{array}$ & 2.93 & .778 \\
\hline $\begin{array}{l}\text { The security guards deployed to this bank are able to use } \\
\text { the latest technology in the bank in security work }\end{array}$ & 2.86 & .762 \\
\hline $\begin{array}{l}\text { The security technology used by the security company } \\
\text { align seamlessly with the technology in the bank }\end{array}$ & 3.04 & .631 \\
\hline $\begin{array}{l}\text { The security company advises the client bank on } \\
\text { technological changes that it should adopt to mitigate } \\
\text { physical security risks }\end{array}$ & 3.51 & .656 \\
$\begin{array}{l}\text { The security company guards are trained on emerging } \\
\text { technological risks affecting the physical security of banks } \\
\text { and other alternate channels they are assigned to secure } \\
\text { (e.g. ATMs) }\end{array}$ & 3.36 & .971 \\
\hline
\end{tabular}

Study findings presented in Table 3 reveal that respondents agreed that the security companies providing security services to the commercial banks used up to date technology in providing security for the bank (Mean $=3.61$ ) and agreed that the security company advises the client bank on technological changes that it should adopt to mitigate physical security risks (Mean = 3.51). However, respondents were neutral to the statements that the security company guards are trained on emerging technological risks affecting the physical security of banks and other alternate channels they are assigned to secure (for example ATMs) (Mean = 3.36), that the security technology used by the security companies align seamlessly with the technology in the bank (Mean $=3.04$ ), and that the security company provides the guards in the bank with the latest security equipment (Mean $=2.93$ ). These findings indicate that technology was a key factor in effective outsourced security services such as having up-to-date technology and advising the bank on required technology changes. These results concur with the results from a study by Gatoto and colleagues (2015) that technology was a key factor that determined the quality of security service provided by these security firms. Gatoto and colleagues (2015) established that in the ever-changing world of private security, protection officers' roles and responsibilities are quickly adapting to a heightened security environment. Therefore, security companies that are quick to adopt innovative ways and current technology are perceived to provide quality security services to their clients. Moreover, respondents were 
neutral to the statement that the security guards deployed to the banks were able to use the latest technology in the bank in security work (Mean $=2.93)$.

\section{Relationship between the vendor and other security stakeholders}

The study's third objective was to explore the effect of relationship between the vendor and other security stakeholders on effective outsourced security services by commercial banks in Nairobi, Kenya. Respondents were required to indicate their level of agreement to the statements provided in relation to the relationship that the vendor security company had with stakeholders. The rating was as follows: 5- Strongly agree, 4 - Agree, 3 - Neutral, 2 - Disagree and 1 - Strongly Disagree. Analysis was though mean scores and standard deviations and results are provided in Table 4.

Table 4: Relationship between the vendor and other security stakeholders

\begin{tabular}{lcc}
\hline Statement & Mean & Standard deviation \\
\hline $\begin{array}{l}\text { The security company has a good relationship with the } \\
\text { bank }\end{array}$ & 4.30 & .519 \\
\hline $\begin{array}{l}\text { The security company has good relationship with the } \\
\text { police }\end{array}$ & 4.16 & .625 \\
\hline $\begin{array}{l}\text { The security company enjoys good relationship with the } \\
\text { government agencies }\end{array}$ & 3.86 & .769 \\
\hline $\begin{array}{l}\text { There is a good relationship between the company and } \\
\text { labour unions }\end{array}$ & 3.65 & 1.113 \\
\hline $\begin{array}{l}\text { The security company has a good relationship with the } \\
\text { public and media }\end{array}$ & 3.43 & .665 \\
\hline
\end{tabular}

The study results presented in Table 4 reveal that respondents agreed that the security companies had a good relationship with the banks (Mean $=4.30$ ) and that the security companies had good relationship with the police (Mean $=4.16)$. Moreover, respondents agreed that the security companies enjoyed good relationship with the government agencies (Mean = 3.86) and that there was a good relationship between the companies and labour unions (Mean = 3.65). However, respondents were neutral regarding the statement that the security companies had a good relationship with the public and media (Mean $=3.43$ ). These findings reveal that the security companies enjoyed good relationships with the commercial banks, the police, government agencies and labour unions, but their relationship with the public and media was not that robust. These findings indicate that relationship with stakeholders in the security industry include the commercial banks, police, other security companies, labour unions, media and the public was key in enabling the security companies to offer effective security services. These findings concur with the results by Bures and Carrapico (2017) that though private security companies provided security services for profit, the government need to effectively regulate the sector by continuously introducing technical and legal regulations to make the sector more effective. Moreover, other stakeholders including the public, labour unions, current clients and potential clients need to participate and collaborate with private security companies to make them more effective on providing quality security services.

\section{Challenges involved in outsourcing effective private security services}

The fourth objective of the study was to analyze the challenges involved in outsourcing effective private security services by commercial banks in Nairobi, Kenya. Various questions were asked to enable the study to accomplish this objective. First, respondents were required to indicate their level of agreement to the statements listed in relation to challenges the banks had encountered in relation to outsourcing security services. The rating was on a 5-point Likert scale (5- Strongly agree, 4 - Agree, 3 - Neutral, 2 - Disagree, 1 - Strongly Disagree). 
Table 4.6 presents the mean and standard deviations that were derived after analysis of the responses.

Table 5: Challenges in outsourcing private security

\begin{tabular}{lcc}
\hline Statement & Mean & Standard deviation \\
\hline $\begin{array}{l}\text { The bank has faced litigation from third parties as a result } \\
\text { of the actions of the company that provides security to the } \\
\text { bank }\end{array}$ & 2.17 & 1.175 \\
\hline $\begin{array}{l}\text { The security company has not been able to provide } \\
\text { security services according to the terms of the contract }\end{array}$ & 2.81 & 1.206 \\
\hline $\begin{array}{l}\text { There have been various disputes between the bank and } \\
\text { the security company that provides security }\end{array}$ & 2.51 & 1.064 \\
\hline $\begin{array}{l}\text { The security company employees do not relate well with } \\
\text { the employees of this bank }\end{array}$ & 2.30 & .878 \\
\hline $\begin{array}{l}\text { The bank has been able to reduce its costs after } \\
\text { outsourcing security services }\end{array}$ & 3.79 & .791 \\
\hline $\begin{array}{l}\text { There have been security breaches after the bank } \\
\text { outsourced security }\end{array}$ & 2.69 & 1.255 \\
\hline
\end{tabular}

Study findings show that respondents agreed to the statement that the banks had been able to reduce their costs after outsourcing security services (Mean $=3.79$ ). However, respondents were neutral on the statements that there had been security breaches after the banks outsourced security (Mean $=2.69$ ), that the security companies had not been able to provide security services according to the terms of the contract (Mean $=2.81$ ) and that there had been various disputes between the banks and the security companies that provided security (Mean $=2.51$ ). Further results indicated that respondents disagreed to the statements that the security companies' employees did not relate well with the employees of the banks (Mean = 2.30) and that the banks had faced litigation from third parties as a result of the actions of the companies that provided security to the banks (Mean $=2.17$ ). These results indicate that the challenges the banks faced to a small extent were security breaches and disputes between the banks and vendor security companies. However, the banks did not have challenges relating to litigation, and poor relationship between the bank's employees and employees of the outsourced private security companies. These findings relate with the findings from a study by Temitope (2015) in Nigeria that the challenges of outsourcing included financial risk, poor planning for the outsourced services, increase in the cost of outsourcing provisions and administration, failure to adhere to quality standards, dilution of control, poor structure to manage the outsourcing function effectively and increase in banks' liabilities to third parties.

\section{Determinants of effectiveness of outsourced private security}

The study used the ordinary least squares regression model to measure the effect of the independent variables on the effectiveness of private security outsourced by commercial banks. The regression model helped to explain the magnitude and direction of effect of the independent variables on the dependent variable. The model that was applied was follows.

$$
\text { EOPS }=\beta_{0}+\beta_{1} F+\beta_{2} T+\beta_{3} R+\beta_{4} C+\mathscr{E}
$$

Where:

EOPS = Effectiveness of Outsourced |Private Security Services

$\mathrm{F}=$ Factors considered by commercial banks while outsourcing private security services

$\mathrm{T}=$ Technology

$\mathrm{R}=$ Relationship between the vendor and other security stakeholders

$\mathrm{C}=$ Challenges involved in outsourcing effective private security services 


\section{$\beta_{0}=$ Constant}

$\beta \mathrm{i}(\mathrm{i}=1,2,3,4,5)=$ The coefficients for the various independent variables $\mathscr{E}$ is the error term which is assumed to be normally distributed with mean zero and constant variance.

The analyzed data is presented in Tables 6 to 8.

Table 6: Model Summary

\begin{tabular}{|l|c|r|r|r|}
\hline Model & R & R Square & $\begin{array}{c}\text { Adjusted R } \\
\text { Square }\end{array}$ & $\begin{array}{c}\text { Std. Error of } \\
\text { the Estimate }\end{array}$ \\
\hline 1 & .733 & .537 & .517 & .587 \\
\hline
\end{tabular}

a. Predictors: (Constant), F, T, R, C

Results in Table 6 reveal that the $r$ squared of the regression was 0.537 indicating that $53.7 \%$ of the effectiveness of outsourced private security services by commercial banks could be explained by factors that the commercial bank considered before outsourcing private security services, technology applied by the private security companies, the relationship between the private security companies and other security stakeholders and the challenges that emanate from outsourced private security services.

The analysis of the variance of the regression model is presented in Table 7. The findings indicate that the model was statistically significant and have predictive power $(\mathrm{F}=26.998$; $\mathrm{P}<$ 0.05). These findings indicate that factors that the commercial bank considered before outsourcing private security services, technology applied by the private security companies, the relationship between the private security companies and other security stakeholders and the challenges that emanate from outsourced private security services can be used to determine effectiveness of outsourced private security services.

Table 7: Analysis of variance

\begin{tabular}{|c|c|c|c|c|c|c|}
\hline & & $\begin{array}{l}\text { Sum of } \\
\text { Squares }\end{array}$ & df & Mean Square & $\mathrm{F}$ & Sig. \\
\hline \multirow[t]{3}{*}{1} & Regression & 37.177 & 4 & \multirow{3}{*}{$\begin{array}{r}9.294 \\
.344\end{array}$} & \multirow[t]{3}{*}{26.998} & \multirow[t]{3}{*}{.000} \\
\hline & Residual & 32.017 & 93 & & & \\
\hline & Total & 69.194 & 97 & & & \\
\hline
\end{tabular}

a. Dependent Variable: EOPS

b. Predictors: (Constant), F, T, R, C

Moreover, study results in Table 8 indicate the effect of factors that the commercial bank considered before outsourcing private security services (F), technology applied by the private security companies (T), the relationship between the private security companies and other security stakeholders (R) and the challenges that emanate from outsourced private security services (C) on effectiveness of outsourced security services (EOPS). 
Table 8: Determinates of Effectiveness of Outsourced security services

\begin{tabular}{|c|c|c|c|c|c|c|}
\hline \multirow{2}{*}{\multicolumn{2}{|c|}{ Model }} & \multicolumn{2}{|c|}{$\begin{array}{c}\text { Unstandardized } \\
\text { Coefficients }\end{array}$} & \multirow{2}{*}{$\begin{array}{c}\begin{array}{c}\text { Standardized } \\
\text { Coefficients }\end{array} \\
\text { Beta }\end{array}$} & \multirow[b]{2}{*}{$\mathrm{t}$} & \multirow[b]{2}{*}{ Sig. } \\
\hline & & $\mathrm{B}$ & Std. Error & & & \\
\hline \multirow[t]{5}{*}{1} & (Constant) & 4.593 & 1.049 & & 4.379 & .000 \\
\hline & $\mathrm{F}$ & .965 & .204 & .463 & 4.733 & .000 \\
\hline & $\mathrm{T}$ & .139 & .116 & .098 & 1.195 & .235 \\
\hline & $\mathrm{R}$ & 1.195 & .130 & .749 & 9.179 & .000 \\
\hline & $\mathrm{C}$ & -.425 & .067 & -.592 & -6.304 & .000 \\
\hline
\end{tabular}

a. Dependent Variable: EOPS

Study results in Table 8 reveal that factors that the commercial bank considered before outsourcing private security services $(F)$ had a positive and significant effect on effectiveness of outsourced private security services by commercial banks $(\beta=0.965 ; p<0.05)$. These results imply that when commercial banks consider more parameters before selecting their security service provided, the effectiveness of the provided security services is expected to improve. These findings concur with study results by Sesi (2014) that careful consideration of Key performance indicators by private security clients resulted in benefits and more effective outsourced private security. The study by Sesi (2014) determined that factors that commercial banks greatly considered in successful implementation of the outsourcing strategy were experience and reputation of the vendor, cost efficiency of the outsourcing, innovative capacity, and technology used, and support services availed by the vendor. Careful consideration of these factors led to benefits such as improved focus on core competence, better operational control and efficiencies, gaining competitive advantage, gaining access to new technology and skills, risk management, quality control, increased focus on core competence and increased productivity.

However, study results show that technology applied by the private security companies (T) in providing security to commercial banks did not have a significant effect on effectiveness of outsourced private security services by commercial banks $(\beta=0.139 ; p>0.05)$. These findings indicate that technology applied by private security companies had not enhanced effectiveness of security services to commercial banks. This can be explained by the fact that the study had established that private security companies had technology that was not very current, and which sometimes failed to align to the needs and technology that commercial banks used.

Study findings further revealed that the relationship between the private security companies and other security stakeholders (R), had a positive and significant effect on effectiveness of outsourced private security services by commercial banks $(\beta=1.195 ; p<0.05)$. These results show that when private security companies improve their collaboration and relationship with commercial banks and other security stakeholders, they can enhance the effectiveness of the security services that they provide to commercial banks.

Lastly, study results show that challenges that emanate from outsourced private security services (C) had a negative and significant effect on effectiveness of outsourced security services to commercial banks $(\beta=-0.425 ; p<0.05)$. These study results imply that presence of challenges had a negative effect on the effectiveness of outsourced private security services. Hence, this implies that fewer challenges would have a positive effect on the services provided to commercial banks. These finding relate with the findings by Temitope (2015) which established that the challenges facing outsourcing in the commercial banking industry in 
Nigeria negatively affected the quality and effectiveness of the outsourced security services. The challenges established to negatively affect effectiveness included financial risk, poor planning for the outsourced services, increase in the cost of outsourcing provisions and administration, failure to adhere to quality standards, dilution of control, and poor structure to manage the outsourcing function effectively.

\section{CONCLUSION AND RECOMMENDATIONS}

The study makes the following conclusions. First, the study concludes that factors that the commercial banks considered before outsourcing private security services had a positive and significant influence on effectiveness of outsourced private security services by commercial bank. Moreover, the study concludes that commercial banks considered the capacity of the private security company to effectively provide the bank with the services, the availability of serviceable physical resources to enable the security company to serve the client effectively, the ability of the security company to identify and speed in resolving emerging or outstanding security related issues affecting their client and the reputation of the security services vendor in the banking sector. Consideration of these factors enabled the bank to ensure that the selected security services provider provided effective security services.

Secondly, the study concludes that technology applied by the private security companies in providing security to commercial banks did not have a significant influence on effectiveness of outsourced private security services by commercial banks. This is despite the security companies using up to date technology in providing security services to the bank and providing advisory services to the client bank on technological changes that the bank should adopt to mitigate physical security risks. However, the study concludes that there were gaps in technological training of the guards and seamless alignment between the security companies' technology and the technology in the bank.

Third, the study concludes that the relationship between the private security companies and other security stakeholders had a positive and significant effect on effectiveness of outsourced private security services by commercial banks. These findings reveal that the security companies enjoyed good relationships with the commercial banks, the police, government agencies and labour unions, but their relationship with the public and media was not that robust.

Lastly, the study concludes that challenges that emanate from outsourced private security services had a negative and significant effect on effectiveness of outsourced security services to commercial banks. The commercial banks had not encountered serious challenges emanating from outsourced security services. The banks had been able to reduce their costs after outsourcing security services However, there had been various reported security breaches even after the banks outsourced security. Additionally, some security companies had not been able to provide security services according to the terms of the contract.

The study makes the following recommendations. First, when seeking a vendor of security services, a commercial bank is supposed to critically consider ability of the vendor to respond within the right time, the vendor's cyber security capabilities, the investigative capabilities of the vendor and the security systems designs. Moreover, commercial banks should also consider countrywide presence of the security company, efficiency in communication with management, ability to deal with emergency cases and history of the company's existence.

Secondly, the study recommends that there should be alarms that are integrated to fire system panels and also surveillance systems should always be integrated with alarm systems. 
Moreover, fire detection systems should be of high standards together with body scanners, CCTV and mobile communications. Additionally, when alarms are integrated to fire panels, redundancies should be incorporated by installing both radio and GPRS system where the client gets automated response when there is any intrusion. Moreover, security technology should always be adequate and should be improved with time as technology evolves.

Third, the study recommends that security companies should have a good relationship with other stakeholders in the industry. The security companies should develop and maintain relationships with internal and external stakeholders to ensure that their cooperation can be obtained when required for key operations. Moreover, the security companies should outsource the services of police where security matters require armed personnel. These interdependences are helpful for the efficient security operations in the commercial banks.

Lastly, the study recommends that private security companies should have competitive pay for the guards and ensure that they are always motivated. Securities companies should also have robust maintenance plans to ensure that there are no delays in repairing security equipment. The companies should also have effective human resource plans to ensure that they deal with challenges of guards not reporting on duty or reporting late and dishonest employees.

\section{References}

Quelin, B. \& Duhamel F. (2013). Bringing Together Strategic Outsourcing and Corporate Strategy: Outsourcing Motives and Risks, European Management Journal, 21 (5), 652 - 663.

McIvor, R. (2014). What is the Right Outsourcing Strategy for Your Process? European Management Journal, 26(1), 24-34.

Fan, Y. (2013). Strategic Outsourcing: Evidence from British Companies. Marketing Intelligence and Planning, 18 (4), 213-219.

Gilley, K. \& Rashid, A. (2010). Making More by Doing Less: An Analysis of Outsourcing and its Effect on Firm Performance. Journal of Management, 26(4), 126 - 134.

Natukunda, C. M., Pitt, M., \& Nabil, A. (2013). Understanding the Outsourcing of Facilities Management Services in Uganda. Journal of Business and Finance, 15(2), 150 - 158.

Jaba, S. (2012). The Private Security Industry in Tanzania: Challenges, Issues and Regulation. Journal of Management, 28(2), 111 - 125.

Machua, E. W. (2014). Outsourcing strategies among commercial banks in Kenya. Master of Business Administration Research Project, University of Nairobi.

Wanjohi, A. M. (2012). Benefits and Risks Involved in Outsourcing Security Services at Kenya Tea Development Authority. Available at: SSRN: https://ssrn.com/=1979428.

Barako, D. \& Gatere, P. (2008). Outsourcing Practices of the Kenyan Banking Sector. African Journal of Accounting, Economics, Finance and Banking Research, 2, (2).

BFID. (2016). Annual report 2016. Nairobi: Central bank of Kenya.

Felson, M. (1994). Crime and Everyday Life: Insight and Implications for Society. Thousand Oaks: Pine Forge Press.

Cohen, E. \& Marcus, F. (1979). Social Change and Crime Rate Trends: A Routine Activity Approach. American Sociological Review. 44:588-605.

Cullen, F., Henson, B., Reyns, B., \& Wilcox, P. (2010). Gender, Adolescent Lifestyles, and Violent Victimization: Implications for Routine Activity Theory. Victims and Offenders, 1(5), 303-328.

Groff, E. (2008). Adding the Temporal and Spatial Aspects of Routine Activities: A Further Test of Routine Activity Theory. Security Journal, 21(1-2), 95-116.

Ayienda, S. A., \& Muturi, W. (2015). Factors Influencing the Adoption of Service Outsourcing among Commercial Banks in Western Kenya. International Journal of Economics, Commerce and Management, 3(11), 920 - 928. 
Sesi, C. I. O. (2014). Challenges of implementing Outsourcing Strategy by Commercial Banks in Kenya. Master of Business Administration Research Project, University of Nairobi.

Gatoto, F. W., Wachira, A, \& Mwenda, L. Service Quality Strategies by Private Security Firms in Kenya. International Journal of Business and Finance Management Research, 3, 83 - 89.

Te, F., Kadar, C., Brüngger, R., \& Cvijikj, I. P. (2016). Human versus Technology: comparing the Effect of Private Security Patrol and Crime Prevention Information System over the Crime Level and Safety perception. TwentyFourth European Conference on Information Systems (ECIS), İstanbul, Turkey.

Bures, 0., \&Carrapico, H. (2017). Private Security Beyond Private Military and Security Companies: Exploring Diversity within Private-public Collaborations and its Consequences for Security Governance. Crime, Law and Social Change, 67, 229-243.

Van Steden, R. \& Sarre, R. (2010). The Tragic Quality of Contract Guards: A Discussion of the reach and Theory of Private Security in the World Today. The Journal of Criminal Justice Research, 1(1), 1-19.

Temitope, J. C. (2015). A Study of Outsourcing and Performance of Commercial Banks in Lagos, Lagos State, Nigeria. Journal for Studies in Management and Planning, 1(11), 598 - 606.

Cooper (2003). Multi method Research: A Synthesis of Styles: London: Sage Publication.

Gay, G (2006). The Practice of Social Research (7th Ed.). Boston: Wadsworth Publishing Company.

Kothari, C. R. (2006). Research Methodology: Methods and Techniques (2nd ed.). New Delhi, India: New Age International Publishers.

CBK. (2017). Commercial Banks and their Locations. Nairobi: CBK. 